\title{
Teaching NeuroImage: Syringomyelia Secondary to Posterior Fossa en Plaque Meningioma
}

Meng Wang, MD, Shengqi Zhao, MD, Yan Hu, MD, Yuchao Zuo, MD, Peichao Zhao, MD, and Fuyou Guo, MD Neurology ${ }^{\circledR}$ 2022;98:e675-e676. doi:10.1212/WNL.0000000000013106

Figure 1 Brain CT

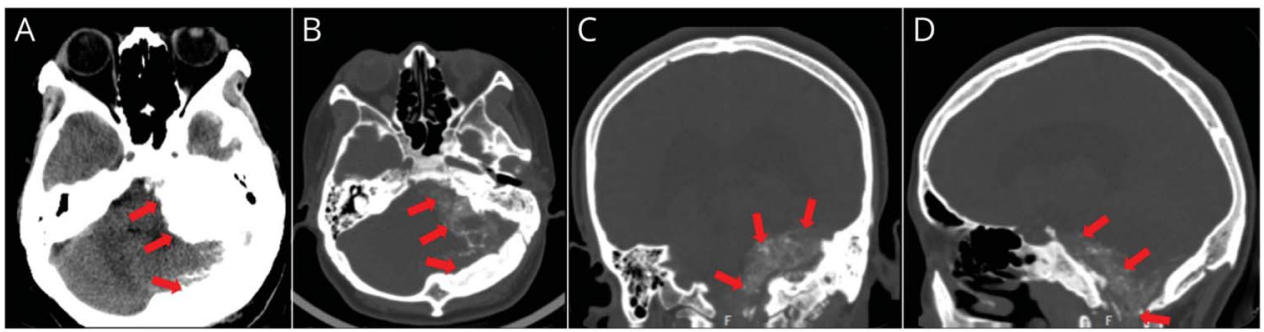

Axial brain windows (A), axial bone windows (B), coronal (C), and sagittal (D) CT show considerable thickening of the left occipital and temporal bones, which is highly suggestive of fibrous dysplasia (red arrows).

Figure 2 Brain MRI

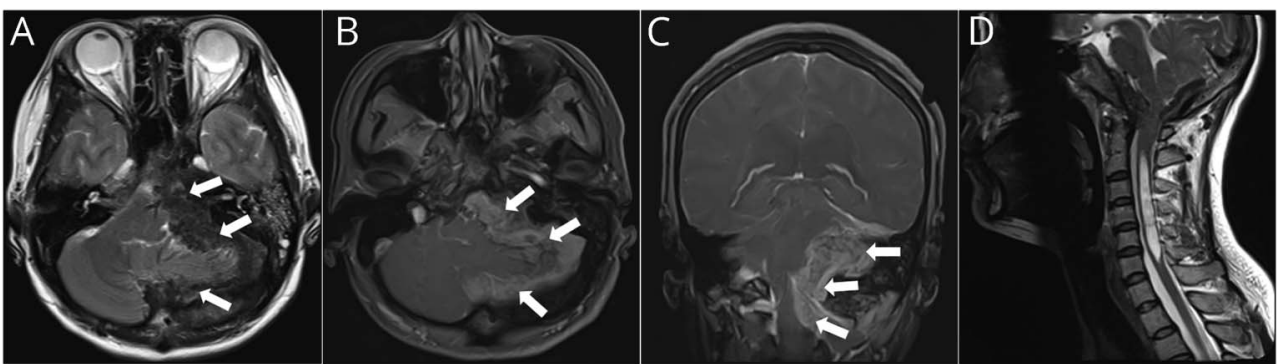

Axial T2-weighted (A), axial postgadolinium T1-weighted (B), and coronal postgadolinium T1-weighted (C) images show a giant posterior fossa lesion. The posterior fossa volume decreased secondary to mass effect of the lesion. The fourth ventricle, brainstem, and left cerebellum are severely compressed. Sagittal T2-weighted (D) image reveals syrinx within the intramedullary cavity extends from C2-C6. The imaging features indicate that the lesion is likely to be a slower growing extra-axial lesion as opposed to a more rapidly growing and/or intramedullary lesion.

A 36-year-old woman presented with a 2-year history of unsteady walking. Examination showed hoarse voice and weakness of the left shoulder. CT revealed thickening of the left occipital and temporal bones (Figure 1), which was thought to be fibrous dysplasia. Brain MRI demonstrated a giant posterior fossa lesion and cervical syringomyelia (Figure 2). The lesion was noted to involve dura mater. Subtotal resection was performed. Pathology confirmed the diagnosis of en plaque meningioma (WHO grade I). Cell proliferation index Ki-67 was $2 \%$. En plaque

\section{Correspondence}

Dr. Guo

chyou666@hotmail.com

\section{MORE ONLINE}

\section{Teaching slides}

links.lww.com/WNL/

B667

M. Wang and S. Zhao contributed equally to this work as co-first authors.

From the Department of Neurosurgery, the First Affiliated Hospital of Zhengzhou University, Zhengzhou, China.

Go to Neurology.org/N for full disclosures. Funding information and disclosures deemed relevant by the authors, if any, are provided at the end of the article. 
meningioma is a rare subtype of meningioma characterized by "sheet-like" patterns of growth. ${ }^{1}$ Significant hyperostosis is often observed.

\section{Study Funding}

The authors report no targeted funding.

\section{Disclosure}

The authors report no disclosures relevant to the manuscript. Go to Neurology.org/N for full disclosures.

\begin{tabular}{lll}
\multicolumn{2}{l}{ Appendix Authors } & \\
\hline Name & Location & Contribution \\
\hline $\begin{array}{l}\text { Meng } \\
\text { Wang, }\end{array}$ & $\begin{array}{l}\text { Department of Neurosurgery, } \\
\text { the First Affiliated Hospital of } \\
\text { MD } \\
\text { Zhengzhou University, } \\
\text { Zhengzhou, China }\end{array}$ & $\begin{array}{l}\text { Drafting/revision of the } \\
\text { manuscript for content, } \\
\text { including medical writing for } \\
\text { content }\end{array}$ \\
\hline $\begin{array}{l}\text { Shengqi } \\
\text { Zhao, } \\
\text { MD }\end{array}$ & $\begin{array}{l}\text { Department of Neurosurgery, } \\
\text { the First Affiliated Hospital of } \\
\text { Zhengzhou University, } \\
\text { Zhengzhou, China }\end{array}$ & $\begin{array}{l}\text { Drafting/revision of the } \\
\text { manuscript for content, } \\
\text { including medical writing for } \\
\text { content }\end{array}$ \\
\hline
\end{tabular}

Appendix (continued)

\begin{tabular}{|c|c|c|}
\hline Name & Location & Contribution \\
\hline $\begin{array}{l}\text { Yan Hu, } \\
\text { MD }\end{array}$ & $\begin{array}{l}\text { Department of Neurosurgery, } \\
\text { the First Affiliated Hospital of } \\
\text { Zhengzhou University, } \\
\text { Zhengzhou, China }\end{array}$ & $\begin{array}{l}\text { Major role in the acquisition of } \\
\text { data }\end{array}$ \\
\hline $\begin{array}{l}\text { Yuchao } \\
\text { Zuo, MD }\end{array}$ & $\begin{array}{l}\text { Department of Neurosurgery, } \\
\text { the First Affiliated Hospital of } \\
\text { Zhengzhou University, } \\
\text { Zhengzhou, China }\end{array}$ & $\begin{array}{l}\text { Major role in the acquisition of } \\
\text { data }\end{array}$ \\
\hline $\begin{array}{l}\text { Peichao } \\
\text { Zhao, } \\
\text { MD }\end{array}$ & $\begin{array}{l}\text { Department of Neurosurgery, } \\
\text { the First Affiliated Hospital of } \\
\text { Zhengzhou University, } \\
\text { Zhengzhou, China }\end{array}$ & $\begin{array}{l}\text { Major role in the acquisition of } \\
\text { data }\end{array}$ \\
\hline $\begin{array}{l}\text { Fuyou } \\
\text { Guo, MD }\end{array}$ & $\begin{array}{l}\text { Department of Neurosurgery, } \\
\text { the First Affiliated Hospital of } \\
\text { Zhengzhou University, } \\
\text { Zhengzhou, China }\end{array}$ & $\begin{array}{l}\text { Drafting/revision of the } \\
\text { manuscript for content, including } \\
\text { medical writing for content, and } \\
\text { study concept or design }\end{array}$ \\
\hline
\end{tabular}

\section{Reference}

1. Shapiro S, Cassis A. Differentiating hyperostotic temporal bone meningioma en plaque and fibrous dysplasia on computed tomographic imaging. JAMA Otolaryngol Head Neck Surg. 2017;143(3):316-317. 


\section{Neurology}

\section{Teaching NeuroImage: Syringomyelia Secondary to Posterior Fossa en Plaque Meningioma}

Meng Wang, Shengqi Zhao, Yan Hu, et al.

Neurology 2022;98;e675-e676 Published Online before print November 22, 2021

DOI 10.1212/WNL.0000000000013106

This information is current as of November 22, 2021

Updated Information \&

Services

References

Subspecialty Collections

Permissions \& Licensing

Reprints including high resolution figures, can be found at: http://n.neurology.org/content/98/6/e675.full

This article cites 1 articles, 0 of which you can access for free at: http://n.neurology.org/content/98/6/e675.full\#ref-list-1

This article, along with others on similar topics, appears in the following collection(s):

CT

http://n.neurology.org/cgi/collection/ct

MRI

http://n.neurology.org/cgi/collection/mri

Primary brain tumor

http://n.neurology.org/cgi/collection/primary_brain_tumor

Information about reproducing this article in parts (figures,tables) or in its entirety can be found online at:

http://www.neurology.org/about/about_the_journal\#permissions

Information about ordering reprints can be found online:

http://n.neurology.org/subscribers/advertise

Neurology ${ }^{\circledR}$ is the official journal of the American Academy of Neurology. Published continuously since 1951, it is now a weekly with 48 issues per year. Copyright @ 2021 American Academy of Neurology. All rights reserved. Print ISSN: 0028-3878. Online ISSN: 1526-632X.

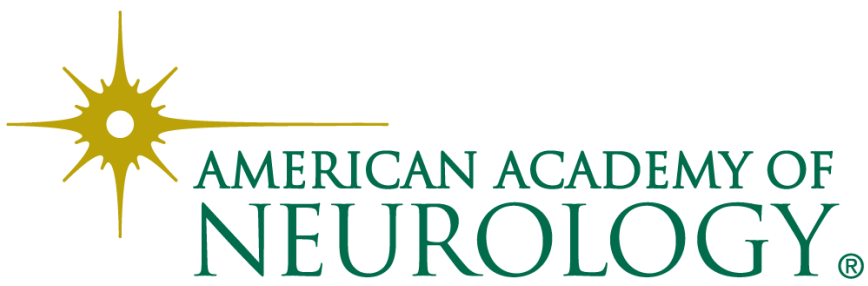

